\title{
Effect of volume fraction of phases and precipitates on the mechanical behavior of UNS S31803 duplex stainless steel
}

\author{
J.C. de Lacerda ${ }^{a, b, *}$, L.C. Cândido ${ }^{a}$, L.B. Godefroid ${ }^{a}$ \\ ${ }^{a}$ REDEMAT, Universidade Federal de Ouro Preto, 35400-000 Ouro Preto, MG, Brazil \\ ${ }^{\mathrm{b}}$ Universidade Federal de Itajubá - Campus Itabira, 35900-000 Itabira, MG, Brazil
}

\section{A R T I C L E I N F O}

\section{Article history:}

Received 22 June 2014

Received in revised form 26 December 2014

Accepted 27 December 2014

Available online 6 January 2015

\section{Keywords:}

Duplex stainless steel

Microstructure

Tensile and fatigue tests

\begin{abstract}
A B S T R A C T
Mechanical properties of a grade UNS S31803 duplex stainless steel were studied. Samples were annealed at three different temperatures, $1060^{\circ} \mathrm{C}, 1200^{\circ} \mathrm{C}$, and $1300^{\circ} \mathrm{C}$, to change the $\alpha / \gamma$ proportion, to precipitate undesirable phases (for example, $\alpha^{\prime}, \sigma$ and chromium nitrides), and to study the effect of the microstructure on the mechanical behavior. Specimens with a thickness of $1.8 \mathrm{~mm}$ were prepared according to ASTM standards and tested at room temperature. Tensile tests were conducted using displacement control at a rate of $5 \mathrm{~mm} / \mathrm{min}$. Force-controlled constant amplitude axial fatigue tests were conducted at a frequency of $30 \mathrm{~Hz}$ and an $R$ stress ratio of 0.1 . Microstructural analyses, performed by optical microscopy and scanning electron microscopy, showed the following modifications to the microstructure: changes in the phase volume fractions, the phase grain growths, and the morphology of the $\gamma$-phase and the precipitation of chromium nitrides in the $\alpha$-phase. The mechanical properties of the steel were significantly changed due to the changed microstructure. The results demonstrate the sensitivity of the steel to the annealing temperature.
\end{abstract}

(c) 2015 Elsevier Ltd. All rights reserved.

\section{Introduction}

Duplex stainless steels are an important class of stainless steels $[1,2]$, with a dual-phase microstructure consisting of approximately equal volume fractions of ferrite $(\alpha)$ and austenite $(\gamma)$. The balance between the two phases is obtained by means of heat treatment, whose temperature depends on the chemical composition of the alloy. As a result of an interesting combination between the austenitic and ferritic stainless steels, these duplex stainless steels combine the best features of both alloys, e.g., stress corrosion cracking resistance and good weldability and reduced costs due to the minor presence of alloying elements in comparison with other stainless steels [3-9]. Due to its low carbon content (i.e., less than $0.03 \%$ ), duplex stainless steels are not susceptible to sensitization (i.e., chromium carbide precipitation in grain boundaries is virtually eliminated), and therefore, they possess high resistance to intergranular corrosion. The addition of nitrogen to the duplex stainless steels increases the fracture toughness and the corrosion resistance of the heat-affected zone compared with welded base metal. With a low percentage of nickel in their chemical compositions, these steels exhibit a superior tensile yield stress than

* Corresponding author at: Universidade Federal de Itajubá - Campus Itabira 35900-000 Itabira, MG, Brazil. Tel.: +55 3138390848.

E-mail address: jlacerda@unifei.edu.br (J.C. de Lacerda). austenitic stainless steels, enabling applications requiring thinner thicknesses and greater corrosion resistances.

An important grade of duplex stainless steels is the so-called "2205" (UNS S31803), which is used in the oil and gas industry in flexible pipes for oil extraction and in the pulp and paper industry in tanks for the storage of chemicals, products and equipment. Their mechanical resistance is promoted by a ferritic structure (interstitial solid solution, mainly $\mathrm{N}$; substitutional solid solution, mainly $\mathrm{Cr}, \mathrm{Mo}, \mathrm{Ni}$; grain refining, with mutual action between the phases), while the austenitic structure guarantees ductility and fracture toughness. Mixing phases also provides a good resistance to stress corrosion cracking and makes the alloy resistant to intergranular corrosion. Its high content of chromium and molybdenum is responsible for resistance against pitting corrosion and uniform corrosion [1,2].

One of the limitations with the use of duplex stainless steels is related to the thermal stability of the material; it is suggested to use only below $250-300{ }^{\circ} \mathrm{C}$. This is because of the large number of undesirable precipitates formed in the $\alpha$ phase at temperatures between 300 and $1000^{\circ} \mathrm{C}$, such as $\alpha^{\prime}, \sigma$ and chromium nitrides. The elements $\mathrm{Cr}$, Mo and $\mathrm{W}$ accelerate the precipitation and expand the range of the temperature. The main effect of the precipitation is the embrittlement of the material and a decreased fracture toughness [9-24]. High temperatures can also change the 
Table 1

Chemical composition of the steel studied (wt\%).

\begin{tabular}{|c|c|c|c|c|c|c|c|c|c|c|c|c|c|}
\hline C & $\mathrm{Cr}$ & $\mathrm{Ni}$ & Mo & $\mathrm{N}$ & $\mathrm{Si}$ & Mn & V & Co & Sn & $\mathrm{Ti}$ & $\mathrm{Nb}$ & $\mathrm{Cu}$ & W \\
\hline 0.02 & 22.38 & 5.35 & 3.04 & 0.151 & 0.31 & 1.82 & 0.06 & 0.02 & 0.01 & 0.01 & 0.04 & 0.2 & 0.01 \\
\hline
\end{tabular}

amount, morphology and distribution of phases, and this may cause loss of toughness and corrosion resistance.

This work studied the tensile and fatigue (i.e., load control) strengths of a UNS S31803 duplex stainless steel. Samples were annealed at three different temperatures to verify thermal effects on the mechanical properties of the material. The temperatures were chosen to cause a change in the volume fraction of $\alpha / \gamma$ phases and the possible precipitation of undesirable phases. These heat treatments were chosen to simulate any high temperature applications of the steel in or any welding procedure found during the fabrication of an engineering structure.

\section{Experimental procedures}

The steel studied was supplied by APERAM South America, Timóteo city, Minas Gerais state, Brazil, in the form of cold-rolled sheets. Its nominal chemical composition is presented in Table 1. Rectangular cross-sections and continuous radius between ends $1.8 \mathrm{~mm}$ thick specimens were prepared according to specific ASTM standards $[25,26]$. The specimens were removed in the longitudinal section of rolling direction, and annealed at three temperatures: $1060^{\circ} \mathrm{C}, 1200^{\circ} \mathrm{C}$ and $1300^{\circ} \mathrm{C}$. Fig. 1 shows the curves of heating and cooling applied for the annealing treatments.

The mechanical tests were performed on a servo-hydraulic MTS machine at room temperature. Tensile tests were performed with displacement control at a rate of $5 \mathrm{~mm} / \mathrm{min}$. The fatigue tests were conducted with load control, at a frequency of $30 \mathrm{~Hz}$ and an $R$ ratio of 0.1. In all mechanical tests, three specimens were used for each situation. Microstructure samples taken from a section longitudinal to the rolling direction were examined on a Leica optical microscope and a JEOL scanning electron microscope. $\alpha$ and $\gamma$ phases were treated and exposed with a reagent consisting of $1 \mathrm{~g}$ of $\mathrm{K}_{2} \mathrm{~S}_{2} \mathrm{O}_{5}$ in $15 \mathrm{ml}$ of $\mathrm{HCl}$ diluted in $85 \mathrm{ml}$ of distilled water, with an exposure time of $5 \mathrm{~s}[20,27]$. Precipitates were collected using an electrolyte solution consisting of oxalic acid solution (10\%) at $5 \mathrm{~V}$ and $15 \mathrm{~s}$ [15-17]. The fracture image analysis was conducted using a JEOL scanning electron microscope.

\section{Results and discussion}

Fig. 2 presents the microstructure of the steel after annealing at the three temperatures. At $1060{ }^{\circ} \mathrm{C}$, it is possible to see a fibrous

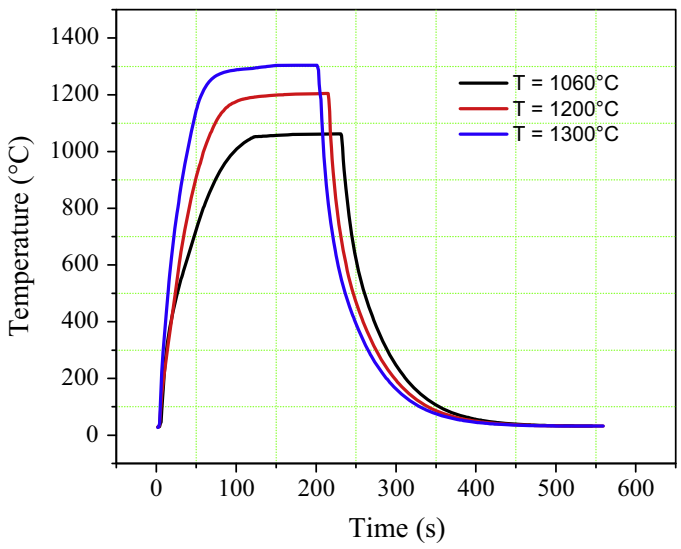

Fig. 1. Heat treatments applied to the UNS S31803 stainless steel.
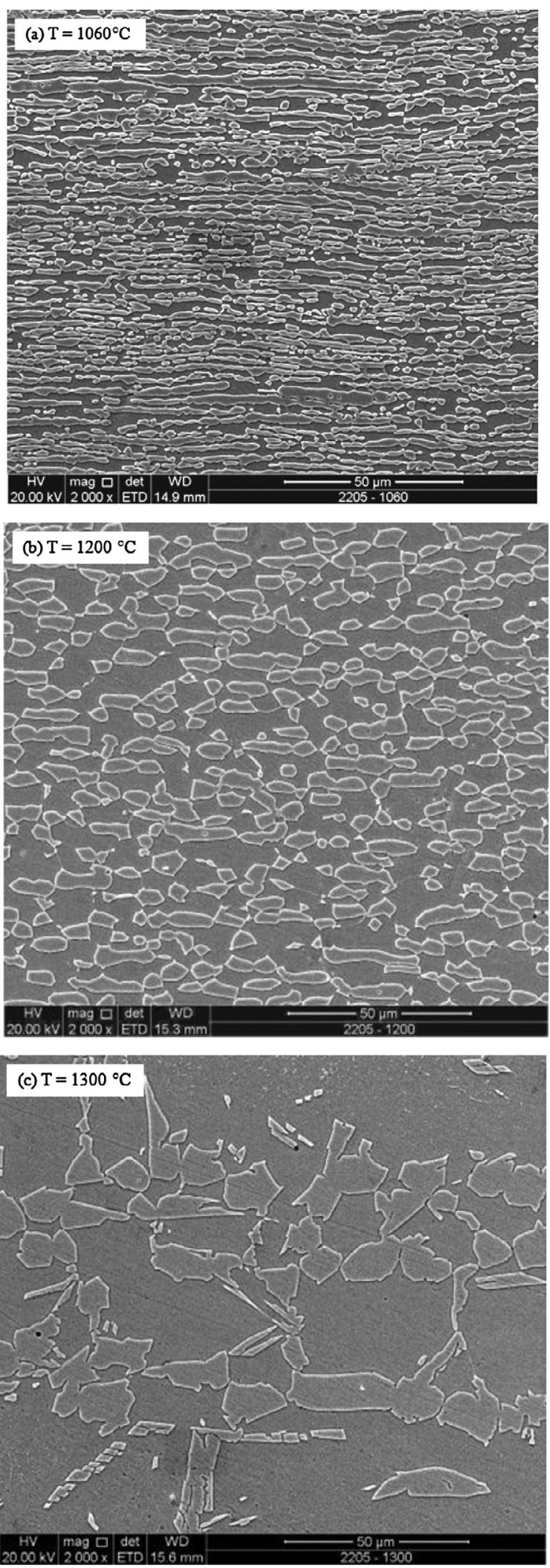

Fig. 2. Microstructures of duplex stainless steel for different annealing temperatures. Ferrite, dark; austenite, light. SEM images. 
Table 2

Volume fraction of $\alpha / \gamma$ phases for different annealing temperatures.

\begin{tabular}{llll}
\hline$T\left({ }^{\circ} \mathrm{C}\right)$ & 1060 & 1200 & 1300 \\
\hline$\alpha$ Phase & $51 \pm 2$ & $62 \pm 4$ & $74 \pm 3$ \\
$\gamma$ Phase & $49 \pm 2$ & $38 \pm 4$ & $26 \pm 3$
\end{tabular}

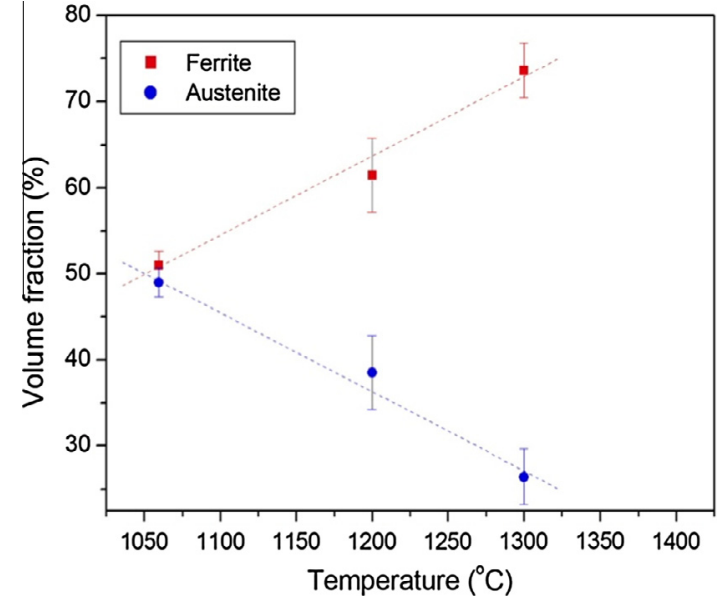

Fig. 3. Variation of volume fraction of phases for different annealing temperatures.

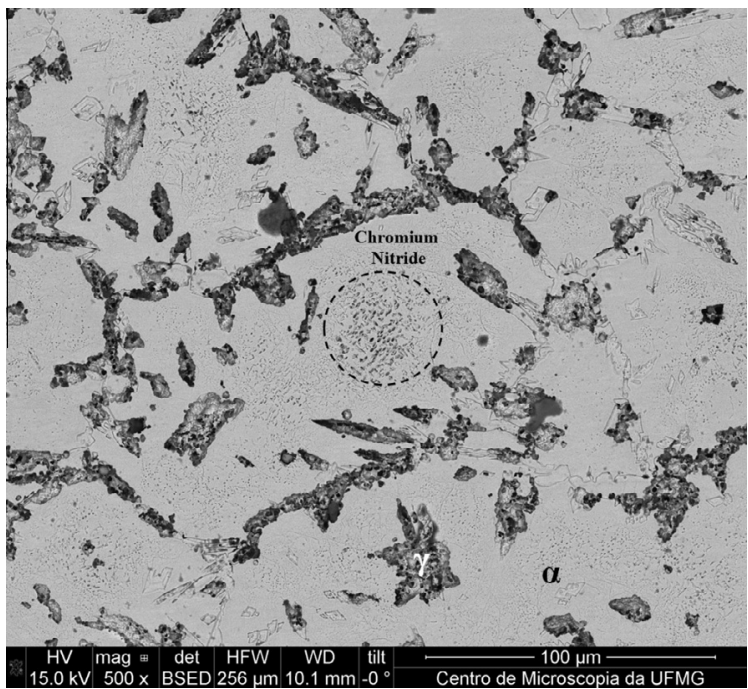

Fig. 4. Presence of chromium nitride precipitates in the duplex stainless steel (circle) after heat treatment at $T=1300^{\circ} \mathrm{C}$. SEM image.

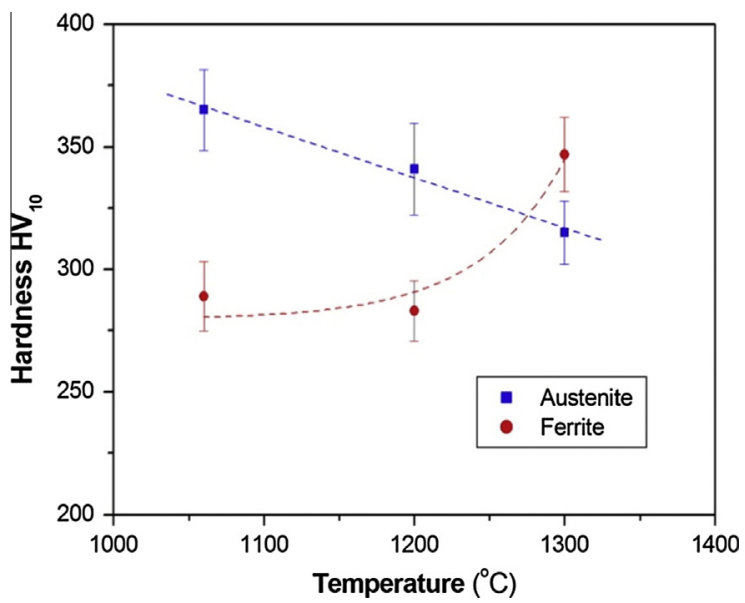

Fig. 5. Variation of phase hardness for different annealing temperatures. microstructure, typical of the rolling process. The austenitic phase appears as islands with a light tone, and the ferritic phase is the matrix that surrounds the austenitic phase and is present in a darker tone. At $1200^{\circ} \mathrm{C}$, the heat treatment leads to a strong recrystallization and grain coarsening of both phases. At $1300^{\circ} \mathrm{C}$, a different morphology is observed, with a larger ferrite grain size,

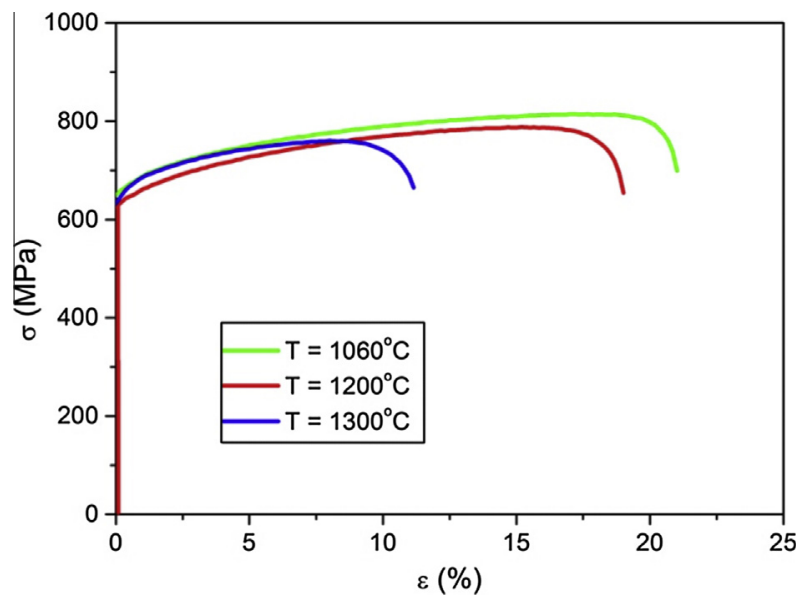

Fig. 6. Tensile stress-strain curves for different annealing temperatures.

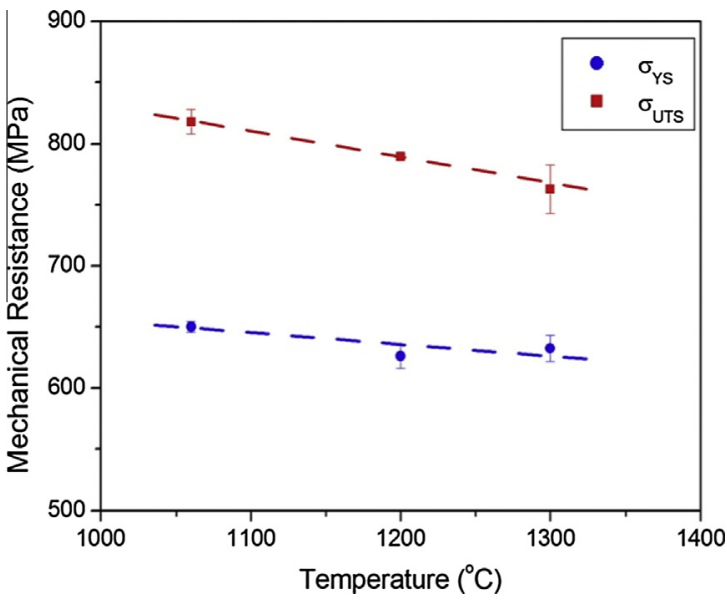

Fig. 7. Tensile mechanical resistance for different annealing temperatures.

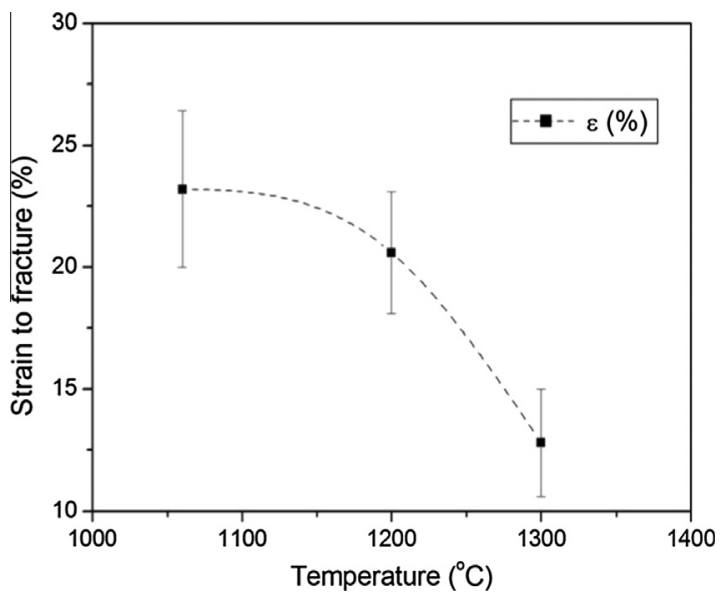

Fig. 8. Tensile strain to fracture for different annealing temperatures. 
and acicular grains of austenite located on the boundaries of the ferrite grains. Annealing also changed the volume fractions of the present phases. Table 2 shows the ferritic phase fraction increasing with the annealing temperature. Fig. 3 shows that the dependence of the phase volume fractions on the annealing temperature follows a linear trend. The effect of annealing temperature on the ferritic grain size can be seen in Table 3 . All results are in accordance with previously reported data in the literature [9].
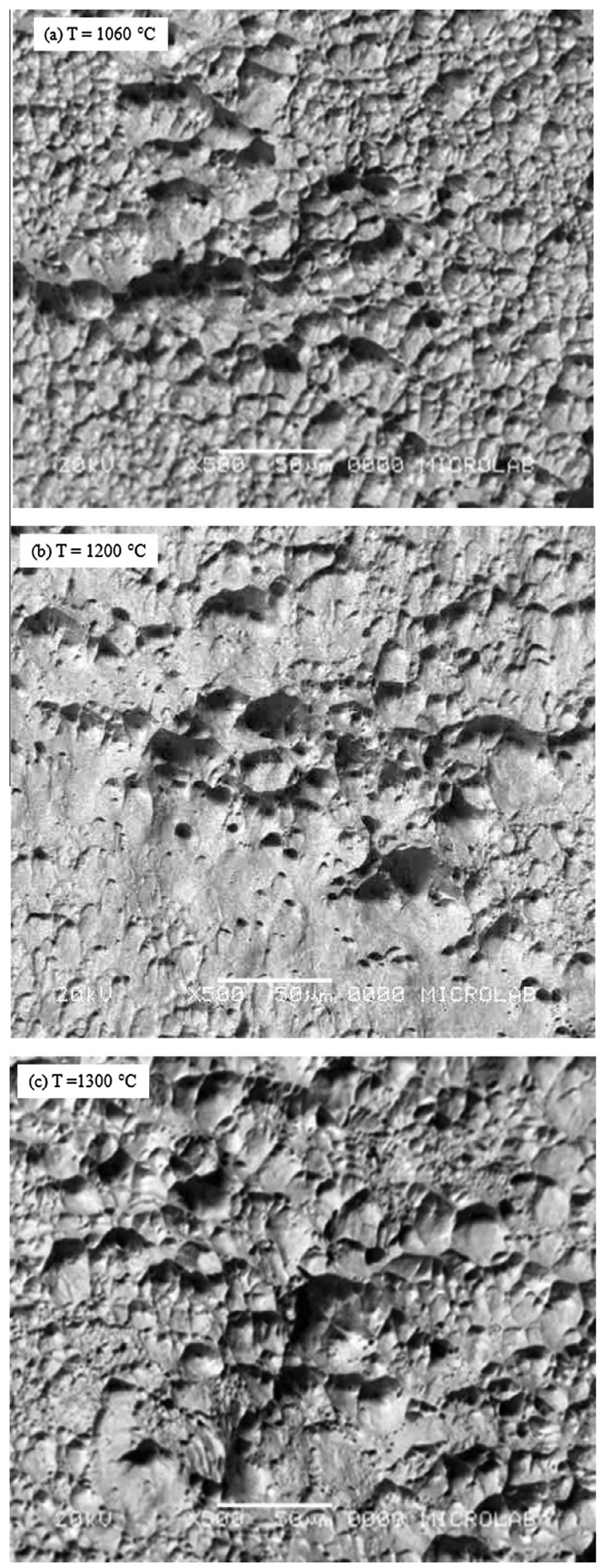

Fig. 9. Fractography of tensile specimens. SEM images.
The chemical etching revealed the presence of chromium nitrides in the material annealed at $1300{ }^{\circ} \mathrm{C}$, precipitated in ferrite grains, as reported by other researchers studying duplex stainless steels with similar volume fractions of ferrite [4,20,28]. Fig. 5 shows fine distributions of these precipitate clusters inside the ferrite grains. The precipitation of chromium nitrides in the steel annealed at $1300{ }^{\circ} \mathrm{C}$ was due to the low solubility of nitrogen in the ferrite and an increase in volume fraction of this phase, approximately $74 \%$, relative to the austenite fraction [28]. It is interesting to note the absence of $\sigma$ phase in the microstructure of steel treated at $1300{ }^{\circ} \mathrm{C}$. This is due to the high cooling rate imposed on the material between 1000 and $600^{\circ} \mathrm{C}\left(20^{\circ} \mathrm{C} / \mathrm{s}\right.$, see Fig. 1), which prevents the formation of this phase [14].

Table 4 and Fig. 5 show the hardness variation (i.e., Vickers microhardness) of the $\alpha / \gamma$ phases as a function of the annealing temperature. It is possible to see a significant increase in the hardness of the ferrite phase, confirming the precipitation of chromium nitrides at $1300^{\circ} \mathrm{C}$ (Fig. 4), even with an increase in the ferritic grain size (Table 3 ).

Fig. 6 shows the engineering stress-strain curves obtained in the tensile tests as a function of the annealing temperatures. The

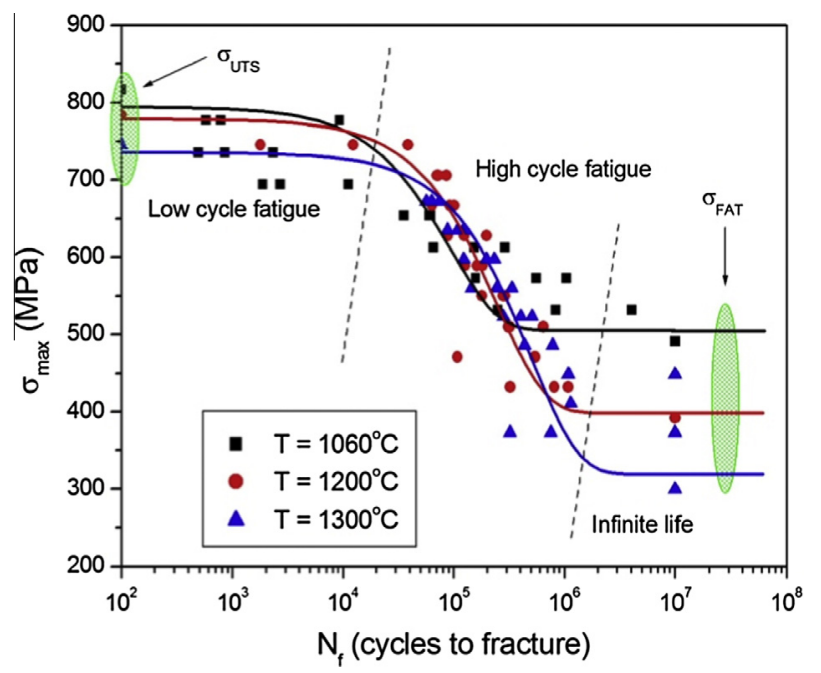

Fig. 10. Maximum stress and fatigue life for different annealing temperatures.

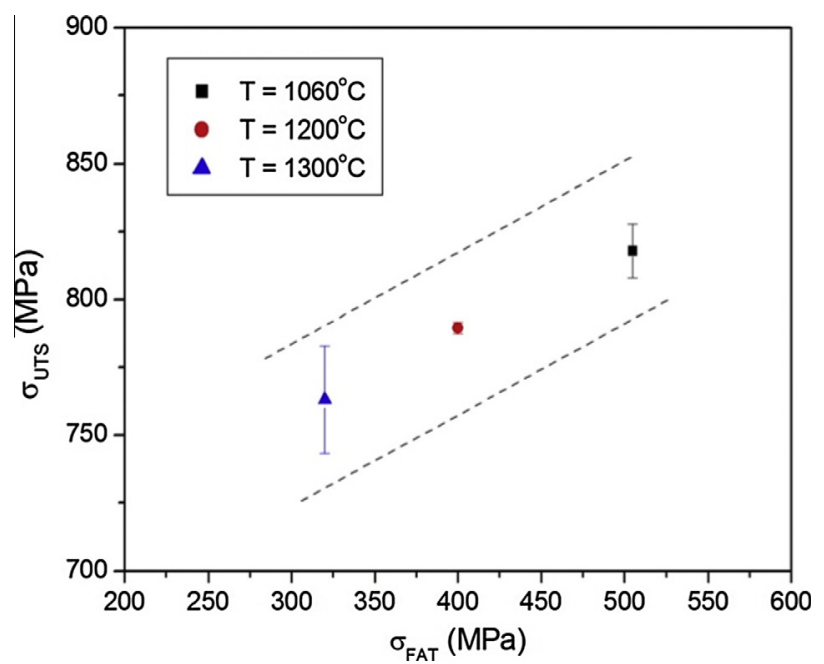

Fig. 11. Ultimate tensile strength and fatigue limit $\left(N_{\mathrm{f}}=10^{7}\right.$ cycles) for different annealing temperatures. 

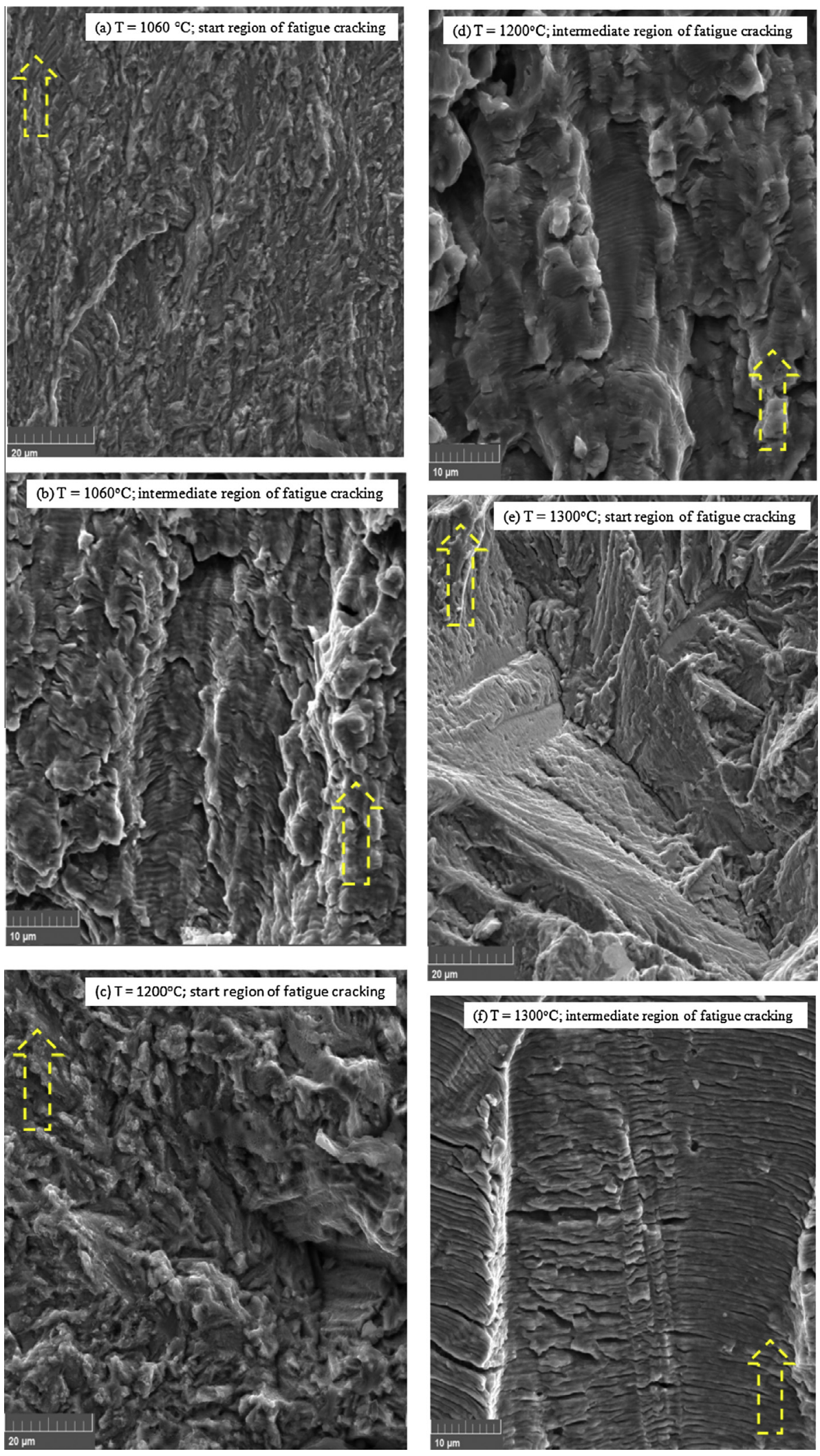

Fig. 12. Fractography of fatigued specimens, start and intermediate regions of cracking. Dashed arrows indicate the direction of crack growth. SEM images.

main mechanical properties obtained from these curves are presented in Table 5. Figs. 7 and 8 show trend curves for the relationships between the mechanical properties and the annealing temperature. A decrease in the mechanical strength is observed for an increasing annealing temperature, due to the increase of grain sizes and changes in the volume fractions and the 
morphologies of the two phases. As the total deformation (and consequently, the fracture toughness) decreases with increasing temperature, it is assumed that the presence of chromium nitrides precipitates also contributes to these results [10-12] despite the tendency for embrittling ferrite (i.e., an observed hardness increase, see Table 4 and Fig. 5).

Regardless of the influence of the annealing temperature on the tensile mechanical properties of duplex stainless steels, the fracture had a ductile nature and developed by a mechanism of nucleation, growth and coalescence indicative of microvoids formation [29]. Fig. 9 illustrates this mechanism for the three studied temperatures. The only difference between the samples is the dimple size, which grows with increasing annealing temperature. The dimple size is correlated with the increase in the grain size of both phases (see Table 3). It is interesting to note that the presence of hardener precipitates in the ferritic phase of the steel treated at $1300{ }^{\circ} \mathrm{C}$ did not change the mechanism of the tensile fracture.

Fig. 10 presents the results obtained in the fatigue tests with load controls, in the form of curves of maximum stress versus the number of cycles to fracture. Exponentially decaying trend curves were fit to better interpret the data and to facilitate a comparison between the three distinct situations. The chart is divided into three regions according to the different behaviors for the fatigued material: low cycle fatigue (i.e., where the maximum stress exceeds the tensile yield stress), high cycle fatigue (i.e., where the maximum stress is below the tensile yield stress), and "infinite life" (i.e., samples that did not fracture after $10^{7}$ cycles). In this last region, the points shown in the figure correspond to the 5 specimens that did not fracture. Increasing the annealing temperature negatively impacts the fatigue performance of the steel, particularly the low cycle behavior and the fatigue limit. The wide dispersion of results in the high cycle fatigue region prevented a verification of the steel performance. Fig. 11 shows the traditional relationship [29] between the ultimate tensile stress and the fatigue limit for the steel studied at the three temperatures.

The study of fatigue resistance in duplex stainless steels has interested several researchers over the last two decades [30-54]. There is a consensus that the fatigue crack nucleation is heavily dependent on characteristics of both phases, such as the volume fraction, morphology, cyclic hardening/softening, crystallographic orientation, activation of slip bands and twinning, and brittle phase precipitation on ferrite. There is also a consensus that fatigue cracking mechanisms depend on the stress/strain level in the material (i.e., low/high fatigue cycle) and that interfaces between phases play an important role in the crack growth resistance. In this study, the ferrite hardness increased with increasing annealing temperature (due to chromium nitrides precipitates; see Figs. 4 and 5) and transferred the plastic deformation to the austenite phase, where fatigue crack nucleation is more probable. Once nucleated in the austenite phase, cracks readily propagated in the more brittle ferrite. The morphology change of austenite grains and the decrease of $\alpha-\gamma$ interfaces with increasing temperature helped to decrease the growth resistance of these cracks. In this way, the degradation of fatigue resistance with increasing temperature was verified.

Fractographic analysis also revealed important features about the effect of annealing temperature on fatigue cracking. To facilitate the comparison between the three distinct situations, specimens that broke after approximately $10^{6}$ cycles (i.e., close to the fatigue limit region) were chosen for each steel. Regardless of the sample treatment condition, fatigue cracking initiated on the surface of the specimen, in a region near a corner (i.e., a stress concentrator site). In all specimens, it was possible to identify the initial nucleation region where fatigue cracking began, the intermediate region of active fatigue cracking and the final tearing region. The nucleation region showed a predominantly transgranular fracture
Table 3

ASTM ferritic and austenitic grain size for different annealing temperatures.

\begin{tabular}{llll}
\hline$T\left({ }^{\circ} \mathrm{C}\right)$ & 1060 & 1200 & 1300 \\
\hline Ferrite & 16.3 & 13.5 & 10.5 \\
Austenite & 16.4 & 14.9 & 11.7 \\
\hline
\end{tabular}

Table 4

Vickers microhardness of the $\alpha / \gamma$ phases for different annealing temperatures.

\begin{tabular}{llll}
\hline$T\left({ }^{\circ} \mathrm{C}\right)$ & 1060 & 1200 & 1300 \\
\hline$\alpha$ Phase & $289 \pm 14$ & $283 \pm 12$ & $347 \pm 15$ \\
$\gamma$ Phase & $365 \pm 16$ & $341 \pm 19$ & $315 \pm 13$ \\
\hline
\end{tabular}

Table 5

Tensile mechanical properties for different annealing temperatures. $\sigma_{\mathrm{YS}}$ : yield stress; $\sigma_{\text {UTS }}$ : ultimate tensile stress; $\varepsilon$ : total strain.

\begin{tabular}{lccc}
\hline$T\left({ }^{\circ} \mathrm{C}\right)$ & 1060 & 1200 & 1300 \\
\hline$\sigma_{\text {YS }}(\mathrm{MPa})$ & $650 \pm 4$ & $626 \pm 10$ & $632 \pm 11$ \\
$\sigma_{\text {UTS }}(\mathrm{MPa})$ & $818 \pm 10$ & $789 \pm 2$ & $763 \pm 20$ \\
$\varepsilon(\%)$ & $23 \pm 3$ & $21 \pm 2$ & $13 \pm 2$ \\
\hline
\end{tabular}

mode, with a "hill-and-valley" type appearance, shear facets, and an associated zig-zag crack path. Such fractures show high roughness and crack deflection angles. At higher growth rates, fracture surfaces remain transgranular but with evidence of striations. In the tearing region, tensile stresses cause the same ductile behavior as shown in the tensile tests [29]. These characteristics are shown in Fig. 12(a-f).

In the region of the fatigue crack nucleation, shear planes with a greater slipping surface area were observed in steel treated at $1300{ }^{\circ} \mathrm{C}$. This morphology is due to the larger grain size and softening of the $\gamma$ phase present in that steel (Tables 3 and 4). In the intermediate/final region of the fatigue cracking, the steel treated at $1300{ }^{\circ} \mathrm{C}$ presented thicker striations. This morphology indicates a higher crack growth rate (Fig. 10) and is primarily due to the hardening ferritic phase (Table 4 ). These fractographic characteristics confirm the deleterious effect of the presence of chromium nitride precipitates in the ferrite grains.

\section{Conclusions}

An investigation of the effects of annealing at $1060^{\circ} \mathrm{C}, 1200{ }^{\circ} \mathrm{C}$ and $1300^{\circ} \mathrm{C}$ on the microstructure and mechanical properties of a UNS S31803 duplex stainless steel reached the following conclusions:

- The increase in temperature caused a significant change in the microstructure of the steel, with changes in the volume fraction and the morphology of the ferrite and austenite phases, increases in the grain size of both phases, and the precipitation of chromium nitrides in the ferrite;

- these microstructural changes resulted in a decreased tensile mechanical strength and ductility of the steel due to the increase in grain size of the two phases, an increase in the volume fraction of ferrite and the presence of chromium nitride precipitates in the ferrite;

- these microstructural changes also caused a decrease in the fatigue crack resistance;

- the nucleation of fatigue cracks was facilitated in the austenitic phase with an increasing annealing temperature due to the transfer of the plastic deformation of the ferritic phase (hardened by the presence of precipitates) to the austenitic phase; 
- the growth of fatigue cracks was facilitated in the ferritic phase with an increasing annealing temperature due to the hardening of their grains (due to the presence of precipitates), and the reduction of $\alpha-\gamma$ interfaces with a grain coarsening of both phases; and

- all the results demonstrate the sensitivity of the steel to the annealing temperature and the care that must be taken in using this steel in applications with large variations in temperature.

\section{Acknowledgment}

The authors acknowledge Ricardo A. Faria, Ph.D. from APERAM South America for the supplied specimens.

\section{References}

[1] Soluções sustentáveis em aço inoxidável para toda a cadeia de óleo e gás. APERAM South America; www.aperam.com (accessed 3.04.2013).

[2] Charles J, Faria RA. Aços inoxidáveis duplex e aplicações em óleo e gás; www. nucleoinox.org.br/upfiles/arquivos/downloads/inox08/pg_247-254.pdf (accessed 03.04.2013).

[3] Davis JR. Stainless steels handbook. The Materials Information Society (ASM); 1996.

[4] Pohl M, Storz O, Glogowski T. Effect of intermetallic precipitations on the properties of duplex stainless steel. Mater Charact 2007;58:65-71.

[5] Neessen F, Bandsma P, Smitweld L. Tankers - a composition in duplex stainless steels. Weld Innov 2001;18:3-8.

[6] Horvarth W, Prantl W, Stuwe HP, Werner E. Influence of thermal cycling on the microstructure of a ferritic-austenitic duplex stainless steel. Mater Charact 1995;34:277-85.

[7] Olsson J, Snis M. Duplex - a new generation of stainless steels for desalination plants. Desalination 2005;205:104-13.

[8] Hussain EAM, Robinson MJ. Erosion-corrosion of 2205 duplex stainless steel in flowing seawater containing sand particles. Corros Sci 2007;49:1737-54.

[9] IMOA (International Molybdenum Association). Practical Guidelines for the Fabrication of Duplex Stainless Steel, 2nd ed. London; 2009. 64 page.

[10] Moreno JRS. Degradação da resistência à corrosão de aços inoxidáveis duplex devido ao envelhecimento em baixas temperaturas por tempos prolongados. Thesis. UFSCar, Brazil; 2004. 196 page.

[11] Pinto TB. Comportamento mecânico de um aço inoxidável duplex do tipo 2205 sob a influência da temperatura e da precipitação de fases frágeis. Thesis. Unicamp, Brazil, 2001. 214 page.

[12] Fontes TF. Efeito da fase $\alpha^{\prime}$ nas propriedades mecânicas e de resistência à corrosão do aço inoxidável duplex UR 52N+. Dissertation. IPEN, Brazil; 2009. 93 page.

[13] Michalska J, Sozanska M. Qualitative and quantitative analysis of $\sigma$ and $\chi$ phases in 2205 duplex stainless steel. Mater Charact 2005;56:355-62.

[14] Sieurin H, Sandström R. Sigma phase precipitation in duplex stainless steel 2205. Mater Sci Eng, A 2007;444:271-6.

[15] Magnabosco R. Kinetics of sigma phase formation in a duplex stainless steel. Mater Res 2009;12(3):321-7.

[16] Magnabosco R, Bruno D. Efeito do envelhecimento a $475 \mathrm{C}$ na microestrutura e corrosão por pite do aço inoxidável dúplex UNS S31803 (SAF 2205). In: 62 Congresso Internacional Anual da ABM, Vitória, Brazil; 2007.

[17] Nascimento AM, Sampaio JP, Machado E, Sobral AVC, Abreu HFG. Estudo das transformações de fase do aço inoxidável duplex UNS S31803 quando submetido a altas temperaturas. Revista Tecnologia 2003;24:13-22. Fortaleza, Brazil.

[18] Badji R, Bouabdallah M, Bacroix B, Kahloun C, Belkessa B, Maza H. Phase tansformation and mechanical behavior in annealed 2205 duplex stainless steel welds. Mater Charact 2008;59:447-53.

[19] Zucato I, Moreira MC, Machado IF, Lebrão SMG. Microstructural characterization and the effect of phase transformations on toughness of the UNS S31803 duplex stainless steel age treated at $850^{\circ} \mathrm{C}$. Mater Res 2002;5:385-9.

[20] Fargas G, Anglada M, Mateo A. Effect of the annealing temperature on the mechanical properties, formability and corrosion resistance of hot-rolled duplex stainless steel. J Mater Process Technol 2009;209:1770-82.

[21] Weng KL, Chen HR, Yang JR. The low-temperature aging embrittlement in a 2205 duplex stainless steel. Mater Sci Eng 2004;A379:119-32.

[22] Hättestrand M, Larsson P, Chai G, Nilsson JO, Odqvist J. Study of decomposition of ferrite in a duplex stainless steel cold worked and aged at $450-500{ }^{\circ} \mathrm{C}$. Mater Sci Eng 2009;A499:489-92.

[23] Silva EM, Albuquerque VHC, Leite JP, Varela ACG, Moura EP, Tavares JMRS. Phase transformations evaluation on a UNS S31803 duplex stainless steel based on non-destructive testing. Mater Sci Eng 2009;A515:126-30.

[24] Chandra K, Singhal R, Kain V, Raja VS. Low-temperature embrittlement of duplex stainless steel: correlation between mechanical and electrochemical behavior. Mater Sci Eng 2010;A527:3904-12.
[25] ASTM E8M. Standard Test Methods for Tension Testing of Metallic Materials.

[26] ASTM E466-07. Standard Practice for Conducting Force Controlled Constant Amplitude Axial Fatigue Tests of Metallic Materials.

[27] Reis TJA, Andrade MS, Godefroid LB. Efeito de tratamentos isotérmicos a 475 C e a $850 \mathrm{C}$ na resistência à fadiga de um aço inoxidável duplex UNS S32304. In: 68 Congresso Internacional Anual da ABM, Belo Horizonte, Brazil; 2012.

[28] Tavares SSM, Terra VF, Pardal MP, Cindra Fonseca MP. Influence of the microstructure on the toughness of a duplex stainless steel UNS S31803. J Mater Sci 2005;40:145-54.

[29] Godefroid LB, Cândido LC, Morais WA. Análise de Falhas. Brazil: Associação Brasileira de Metalurgia, Materiais e Mineração - ABM; 2012.

[30] Llanes L, Mateo A, Anglada M. Cyclic response of duplex stainless steel - an intrinsic two-phase description. In: Proceedings of the Sixth International Fatigue Conference. Berlin/Germany, Pergamon; 1996. p. 87-92.

[31] Mateo A, Violan P, Llanes L, Mendez J, Anglada M. Fatigue life of duplex stainless steel - influence of ageing and environment. In: Proceedings of the Sixth International Fatigue Conference. Berlin/Germany, Pergamon; 1996. p. 209-214.

[32] Chai G, Sundqvist M. Fatigue strength and crack behavior of duplex stainless steel. In: Proceedings of the Seventh International Fatigue Conference. Beijing/ China, EMAS, 1999. p. 175-180.

[33] Baffie N, Gironès A, Mateo A, Anglada M, Stolarz J. Influence of interfaces on LCF short crack propagation in the bulk in single phase and in duplex stainless steels. In: Proceedings of the Seventh International Fatigue Conference. Beijing/China, EMAS, 1999. p. 359-364.

[34] Mateo A, Llanes L, Akdut N, Anglada M. High cycle fatigue behaviour of a standard duplex stainless steel plate and bar. Mater Sci Eng, A 2001;319321:516-20.

[35] Bugat S, Besson J, Gourgues AS, N'Guyen F, Pineau A. Microstructure and damage initiation in duplex stainless steels. Mater Sci Eng, A 2001;317:32-6.

[36] Vogt JB, Massol K, Foct J. Role of microstructure on fatigue properties of $475 \mathrm{C}$ aged duplex stainless steel. Int J Fatigue 2002;24:627-33.

[37] Mateo A, Gironès A, Llanes L, Anglada, M. Cyclic deformation and fatigue behavior of duplex stainless steel. In: Proceedings of the Eighth International Fatigue Conference. Stockholm/Sweden, EMAS; 2002. p. 461-472.

[38] Stolarz J, Baffie N. Low cycle fatigue of aged duplex steels. In: Proceedings of the Eighth International Fatigue Conference. Stockholm/Sweden, EMAS; 2002. p. 2831-2838.

[39] Mateo A, Llanes L, Akdut N, Stolarz J, Anglada M. Anisotropy effects on the fatigue behaviour of rolled duplex stainless steels. Int J Fatigue 2003;25:481-8.

[40] Gironès A, Villechaise P, Mateo A, Anglada M, Méndez J. EBSD studies on the influence of texture on the surface damage mechanisms developed in cyclically loaded aged duplex stainless steels. Mater Sci Eng, A 2004;387389:516-21.

[41] Chai G. Fatigue behavior of duplex stainless steels in the very high cycle regime. Int J Fatigue 2006;28:1611-7.

[42] Düber O, Künkler B, Krupp U, Christ HJ, Fritzen CP. Short crack propagation in duplex stainless steel. In: Proceedings of the Ninth International Fatigue Conference. Atlanta/USA, Elsevier; 2006, CD_ROM.

[43] Alvarez-Armas I, Marinelli MC, Malarría JA, Degallaix S, Armas AF Microstructure associated with crack initiation during low-cycle fatigue in a low nitrogen duplex stainless steel. Int J Fatigue 2007;29:758-64.

[44] Armas AF, Hereñú S, Alvares-Armas I, Degallaix S, Condó A, Lovely F. The influence of temperature on the cyclic behavior of aged and unaged super duplex stainless steels. Mater Sci Eng, A 2008;491:434-9.

[45] El Bartali A, Aubin V, Sabatier L, Villechaise P, Degallaix S. Identification and analysis of slip systems activated during low-cycle fatigue in a duplex stainless steel. Scripta Mater 2008;59:1231-4.

[46] Balbi M, Avalos M, El Bartali A, Alvarez-Armas I. Microcrack growth and fatigue behavior of a duplex stainless steel. Int J Fatigue 2009;31:2006-13.

[47] El Bartali A, Aubin V, Degallaix S. Surface observation and measurement techniques to study the fatigue damage micromechanisms in a duplex stainless steel. Int J Fatigue 2009;31:2049-55.

[48] Marinelli MC, El Bartali A, Signorelli JW, Evrard P, Aubin V, Armas IA, et al. Activated slip systems and microcrack path in LCF of a duplex stainless steel. Mater Sci Eng, A 2009;509:81-8.

[49] Sahu JK, Gosh RN, Christ HJ. Low cycle fatigue behavior of duplex stainless steel - influence of isothermal aging treatment. Fatigue Fract Eng Mater Struct 2009;33:77-86.

[50] Christ HJ, Düber O, Fritzen CP, Knobbe H, Köster P, Krupp U, et al. Propagation behaviour of microstructural short fatigue cracks in the high-cycle fatigue regime. Comput Mater Sci 2009;46:561-5.

[51] Alvares-Armas I, Knobbe H, Marinelli MC, Balbi M, Hereñú S, Krupp U. Experimental characterization of short fatigue crack kinetics in an austenoferritic duplex steel. Proc Eng 2011;10:1491-6.

[52] Sahu JK, Krupp U, Christ H. Fatigue crack initiation behavior in embrittled austenitic-ferritic stainless steel. Int J Fatigue 2012;45:08-14.

[53] Strubbia R, Hereñú S, Marinelli MC, Alvares-Armas I. Short crack nucleation and growth in lean duplex stainless steel fatigue at room temperature. Int J Fatigue 2012;41:90-4.

[54] Alvares-Armas I, Krupp U, Balbi M, Hereñú S, Marinelli MC, Knobbe H. Growth of short cracks during low and high cycle fatigue in a duplex stainless steel. Int J Fatigue 2012;41:95-100. 